\title{
The Difference of Antibacterial Power Between Cocoa Peel (Theobroma cacao) Extract 6\% Compared to NaOCL 5\% Againts Lactobacillus acidophilus
}

\author{
Tamara Yuanita $^{1}$, Dian Agustin Wahjuningrum ${ }^{1}$, and Mega Selvia² \\ ${ }^{1}$ Conservative Dentistry Department, Faculty of Dentistry, Airlangga University, Surabaya, Indonesia \\ ${ }^{2}$ Student of the Faculty of Dentistry, Airlangga University, Surabaya, Indonesia
}

\begin{abstract}
Background: Lactobacillus acidophilus is a gram-positive rod-shaped bacteria which mostly causes chronic caries lesions. In the process of cavity preparation it is reported that it is not possible to remove all microorganisms and even bacteria can survive even after removal of the necrotic tissue. Efforts to stop the growth of these bacteria are by chemical cavity cleanser using a 5\% NaOCl, but this material have disadvantages including irritating periradicular tissue, unpleasant odor, and toxicity. Due to its disadvantages, it is hoped that natural ingredients can be used as alternatives. Cocoa peel extract has active compounds of tannins, flavonoids, alkaloids, terpenoids, and saponins which have antibacterial ability with a concentration of $6 \%$ according to the non-toxic minimum kill concentration of Lactobacillus acidophilus. Purpose: To analyze the difference in antibacterial power between the extract of cocoa bark with a concentration of 6\% compared to 5\% NaOCl against Lactobacillus acidophilus. Methods: This study was a laboratory experimental in vitro with a post test-only control group design. Using diffusion method against Lactobacillus acidophilus grown in tubes containing $B H I B$, then cultured in a petridish which contains a nutrient agar and is divided into 2 parts extract cocoa peel extract $6 \%$ and $\mathrm{NaOCl} 5 \%$, then each petridish given a paper disc that has been poured $10 \mu \mathrm{l}$ by each material, then incubated in the incubator for $2 \times 24$ hours at $37^{\circ} \mathrm{C}$ and observe the diameter of the inhibition zone formed using a caliper. Results: The average diameter of the inhibition zone formed in the 6\% cocoa peel extract was $11.8375 \mathrm{~mm}$ and $\mathrm{NaOCl} 5 \%$ was 26.0344 mm against Lactobacillus acidophilus. Conclusion: There is a difference in antibacterial power between $6 \%$ cocoa peel extract and 5\% NaOCl against Lactobacillus acidophilus.
\end{abstract}

Keywords: Cocoa peel extract; $\mathrm{NaOCl}$; Lactobacillus acidophilus

Correspondence: Tamara Yuanita, Conservative Dentistry Department, Faculty of Dental Medicine, Universitas Airlangga. Jl Mayjen. Prof. Dr. Moestopo No. 47, Surabaya 60132, Indonesia. Email: tamara-y@fkg.unair.ac.id,

\section{INTRODUCTION}

Dental caries is one of the most chronic infectious diseases in the world. ${ }^{1}$ Global prevalence shows that about $60-90 \%$ of children and nearly $100 \%$ of the world's adult population suffer from dental caries. ${ }^{2}$ According to Riskesdas 2018 data, out of $67.3 \%$ of Indonesian children aged 5 years have a DMFt caries index $>6 \%$ (poor). Dental caries is a complex and dynamic process.

Many factors can be the causes and risk factors for caries. ${ }^{2}$ The oral cavity has a unique ecology for the growth and development of microorganisms to form biofilms. The main etiology of caries is that bacteria that are cariogenic in nature ferment carbohydrates and produce acids which in turn result in a demineralization process on the tooth surface. ${ }^{3}$ Streptococcus mutans and Lactobacillus acidophilus are often considered the two most important cariogenic bacteria associated with dentinal caries. Lactobacillus acidophilus is a gram-positive facultative anaerobic bacteria can be found in the cavities of the teeth on the occlusal surface.
These bacteria can cause rampant caries in children aged 3-12 years and cause caries in primary teeth and permanent molars which usually grow by 6 years of age. ${ }^{3}$

The way to eliminate the caries-causing bacteria is to carry out the preparation and cleaning of the cavity. ${ }^{4}$ During the cavity preparation process, the success of the restoration can be influenced by the residual bacteria adhering to the cavity wall. The remaining bacteria is capable of causing micro-leakage which may lead to pulp irritation, secondary caries, and post-restoration sensitivity. ${ }^{4}$ One study stated that half of all restorations in carious teeth had to undergo replacement restorations. $40 \%$ of them are caused by bacterial contamination which causes secondary caries. Tooth tissue affected by caries must be cleaned by carrying out preparations, however after preparation it will produce a smear layer and residual bacteria that remain attached to the cavity wall, therefore to eliminate bacteria optimally it is necessary to prepare the cavity before restoration using a cavity cleanser. ${ }^{4}$ This fact encourages the development of a cavity cleanser that can kill bacteria that cause secondary 
caries. ${ }^{3}$ In the field of dentistry, the cavity cleanser is a material to remove debris and bacteria in the cavity. ${ }^{5}$ There are various kinds of cavity cleansers that can be used by dentists, one of which is $\mathrm{NaOCl}{ }^{4}$

Sodium hypochlorite $(\mathrm{NaOCl})$ is an effective organic solvent and has been widely used in dentistry as a cleaning agent after being previously used for antimicrobial irrigation in endodontic treatments. ${ }^{4} \mathrm{NaOCl}$ is able to change cellular metabolism and destroy phospholipids. $\mathrm{NaOCl}$ also initiates chloramine formation and irreversibly inactivates bacterial enzymes. ${ }^{6} \mathrm{NaOCl} 5 \%$ is the most effective solution used as an antibacterial. ${ }^{7}$ According to research conducted by Tanumihardja in 2010, sodium hypochlorite $5 \%$ is an antiseptic solution that is potential and effective in killing pathogens such as gram-positive, gram-negative, fungi, and spores. $\mathrm{NaOCl}$ has several disadvantages because it is a very strong oxidizing solution that can produce corrosive reactions; it must therefore be applied very carefully. In addition, $\mathrm{NaOCl}$ tends to be used to bleach clothes, has an unpleasant taste and smell and is able to irritate the surrounding tissue, especially at high concentrations. ${ }^{4}$

Cocoa bark extract (Theobroma cacao) has beneficial properties, including phenolic compounds, tannins, saponins, terpenoids, and flavonoids. ${ }^{8}$ Phenolic compounds, flavonoids, tannins, and terpenoids in the skin of cocoa peel are known to have antimicrobial activity by reacting with the lipid fraction of the bacterial plasma membrane resulting in changes in membrane permeability which, if accumulated continuously, can result in lysis of intracellular material due to the formation of cavities in the lipids bilayer. ${ }^{9}$ Indonesia is the 3rd largest cocoa producer in the world. The cocoa plantation area in 2012 was recorded at 1,732,954 hectares and produced 936,266 tonnes. ${ }^{10}$ The use of cocoa waste is still very limited, where people only use cocoa shells as animal feed and compost. ${ }^{11}$ In this study, cocoa shell extract with a concentration of $6 \%$ was used against Lactobacillus acidophilus because based on research conducted by Fitriana et al in 2019, in the MTTtest assay on Baby Hamster Kidney-21 fibroblast cells, it was found that the concentration of cocoa peel extract was above $6.25 \%$. has a toxic effect. In addition, the choice of $5 \% \mathrm{NaOCl}$ material as a cavity cleanser and not using $\mathrm{CHX}$ because $5 \% \mathrm{NaOCl}$ is an ingredient with very strong antibacterial activity. ${ }^{12} \mathrm{It}$ is not uncommon to use $\mathrm{CHX}$ as a cavity cleanser to cause allergic reactions such as redness of the gingival mucosa and can even cause anaphylactic shock. ${ }^{13}$

In dentistry, the use of herbal alternatives has long been recognized for their good antibacterial, analgesic, antiinflammatory, antioxidant and biocompatibility effects ${ }^{14}$ so that research is needed to prove the difference in antibacterial power between cocoa bark extract (Theobroma cacao) and $5 \% \mathrm{NaOCl}$ against bacteria Lactobacillusacidophilus.

\section{MATERIALS AND METHODS}

The type of research used was an experimental in vitro study with a post-test-only control group design. The sample used was the stock of bacteria Lactobacillus acidophilus obtained from the Research Center of the Faculty of Dentistry, Airlangga University.

In this study, researchers used cocoa peel obtained from Banyuwangi. $1 \mathrm{~kg}$ of cocoa peel cleaned and then cut into thin strips to a thickness of 1-2 mm. The skin of the chopped cocoa peel is dried in the open air for three days. After the peel are dry, mash them in a blender until they become a fine powder.15 Then 40 grams of cocoa peel powder is macerated using a solvent by soaking $400 \mathrm{ml}$ of $70 \%$ ethanol and stirring several times, leaving it for 24 hours in an erlenmeyer. The immersion was carried out at room temperature in the shacker at a speed of $120 \mathrm{rpm}$ continuously for 24 hours. After 24 hours, the solution was filtered using filter paper Whatman no. 41, so that the maserate is obtained. The solvent (ethanol) in the macerate was evaporated until it was free from the ethanol solvent using a Rotary Vacuum Evaporator until a pure extract was obtained. $2 \mathrm{ml}$ of concentrated extract is taken and then diluted with distilled water to reach a concentration of $6 \%$.

Lactobacillus acidophilus to be used were taken from stocks Lactobacillus acidophilus using sterile osse and planted on Brain Heart Infusion Broth (BHIB) media. Then, it was incubated for 24 hours at $37^{\circ} \mathrm{C}$. The culture was matched with thestandard Mc.Farland, then thinned until it reached thestandard of Mc.Farland 0.5 or equivalent to $1.5 \times 108 \mathrm{CFU} / \mathrm{ml}$ to obtain a certain concentration of bacteria. ${ }^{16}$

Prepare 16 petridishes containing nutrients so that each plate is divided into 2 treatment parts. Takebacteria cultures Lactobacillus acidophilus from BHIB which have been equalized.cultures were Lactobacillus acidophilus grown on media nutrient using a cotton swab using themethod swab. Spread evenly on the surface in order. Drop $10 \mu 16 \%$ cocoa peel and $5 \% \mathrm{NaOCl}$ on a paper disk or disc paper. Place the paper disk that has been dripped with $6 \%$ cocoa peel skin extract and $5 \% \mathrm{NaOCl}$ on each agar surface. Incubation for 24 hours in an incubator with a temperature of $37^{\circ} \mathrm{C}$. Observing the inhibition zone, the inhibition zone resulted from each treatment has different diameters and irregular shapes. Observations were made by measuring the longest diameter formed and the shortest diameter by using a calipers in millimeters $(\mathrm{mm})$ and then added together then divided by 2 to obtain the average.

\section{RESULTS}

At the beginning of the study, the preparation of extracts and phytochemical tests was carried out on the extract of cocoa

Table 1. Phytochemical test results of cocoa peel extract

\begin{tabular}{lc}
\hline Contents & Percentage $(\%)$ \\
\hline Flavonoid & 3.05 \\
Alkaloids & 5.02 \\
Tannins & 4.15 \\
Saponin & 4.08 \\
Terpenoids & 2.11 \\
\hline
\end{tabular}




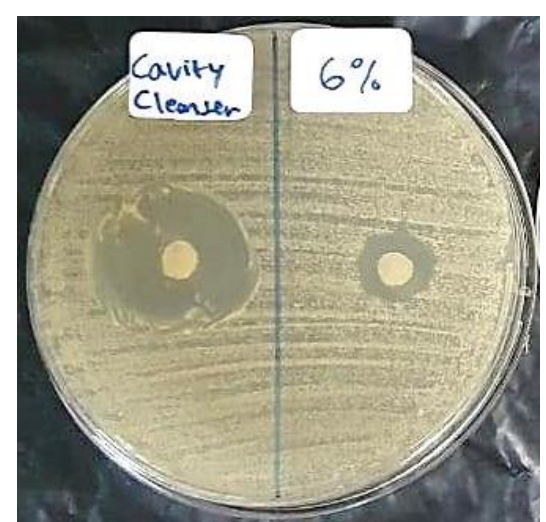

Figure 1. The results of differences in the inhibition zone in the extract of $6 \%$ cacao peel extract and $5 \% \mathrm{NaOCl}$ against Lactobacillus acidophilus.

peel at Balai Penelitian dan Konsultasi Industri (BPKI) Surabaya. Table 1 shown the test results of phytochemical cocoa fruit peel extract.

This study was conducted to analyze the differences in antibacterial activity between the cocoa peel extract with a concentration of $6 \%$ compared to $5 \% \mathrm{NaOCl}$ against Lactobacillus acidophilus by diffusion method. In this study, there were 2 treatment groups, namely the cocoa peel extract concentration group $6 \%$ which is the minimum kill concentration of non-toxic cocoa peel extract and the $5 \% \mathrm{NaOCl}$ group. There were sixteen replications of the $6 \%$ cocoa peel extract and 5\% NaOCl. From the research conducted, the results are as shown below.

\section{DISCUSSION}

The antibacterial used in this study were extracts of cocoa peel with an effective concentration that was not toxic to the bacteria Lactobacillus acidophilus, namely 6\% and $\mathrm{NaOCl} 5 \%$. To determine the content contained in the extract of the cocoa peel, a phytochemical test was carried out. Phytochemical test was conducted at BPKI Ketintang Surabaya. The results obtained from the phytochemical test were the content of saponins (4.08\%), flavonoids $(3.05 \%)$, tannins $(4.15 \%)$, terpenoids $(2.11 \%)$, alkaloids $(5.02 \%)$. These results prove the theory that the cocoa peel extract has antibacterial properties.

The results obtained from the antibacterial test mean and standard deviation of inhibition zone diameter (table 5.1) antibacterial extract of $6 \%$ cocoa peel has a diameter of $11.8375 \mathrm{~mm}$ and $\mathrm{NaOCl} \%$ has a diameter of $26.0344 \mathrm{~mm}$. From the test results, it was found that the mean diameter of the inhibition zone formed in the cacao peel extract group was $6 \%$ lower than in the $5 \% \mathrm{NaOCl}$ group.

The difference in antibacterial power may be due to differences in how antibacterials work in each material. $\mathrm{NaOCl}$ works by neutralizing amino acids into water and salt. The hydroxyl ions released in this process will act on membrane proteins so that the membrane proteins undergo denaturation. ${ }^{17}$ While the cocoa shell extract works through

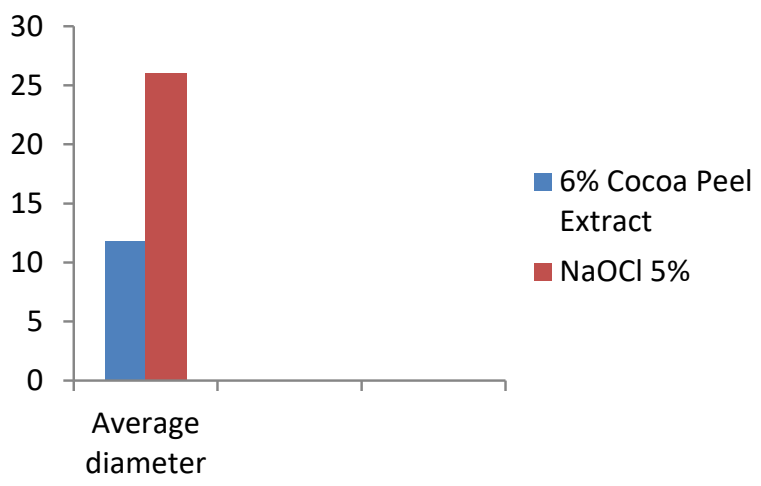

Figure 2. Bar graph of mean inhibition zone diameter ( $\mathrm{mm})$ antibacterial value of $6 \%$ cocoa peel extract and $5 \%$ $\mathrm{NaOCl}$ against bacteria Lactobacillus acidophilus.

5 chemical compounds contained therein. Of the 5 chemical compounds, the most important role as antibacterial is the $3.05 \%$ flavonoid compound. In the cocoa shell extract, flavonoids contain active ingredients in the form of catechins and anthocyanins which play a role in the antibacterial and antioxidant processes by denaturing bacterial proteins and digesting genetic material in bacteria. ${ }^{18}$ Saponins of $4.08 \%$ will diffuse through the outer membrane and vulnerable cell walls and then bind to the cytoplasmic membrane so that it disrupts and reduces the stability of the cell membrane. This causes the cytoplasm to leak out of the cell resulting in cell death. ${ }^{19}$ There are also $4.15 \%$ tannins which act as antibacterial compounds because they can bind to proteins that form bacterial cell walls so that the formation of cell walls becomes less than perfect. ${ }^{20}$ Addition, In tannin is able to inactivate the bacterial adhesin that transport proteins and the formation of a layer of cell wall is disrupted. If the cell wall is formed imperfectly it will cause bacterial cell lysis due to high osmotic pressure. ${ }^{21}$ Alkaloid compounds $5.02 \%$ have antibacterial properties because they contain quaternary aromatic groups capable of interacting with DNA, besides that alkaloids are also able to disrupt the integrity of the peptidoglycan constituent components in bacterial cells which will cause the cell wall layer not to form completely and cause cell death. ${ }^{22}$ Meanwhile, 2.11\% terpenoids are lipophilic so they easily enter into bacterial cells. This can lead to disruption of cell membrane integrity, leakage of cellular content and denaturation of cytoplasmic proteins which lead to cell death. ${ }^{23}$

The diameter of the inhibition zone at $5 \% \mathrm{NaOCl}$ shows a higher number compared to $6 \%$ cacao bark extract because $5 \% \mathrm{NaOCl}$ contains chlorine which is a strong oxidant which has antibacterial properties with the ability to inhibit bacterial enzymes and disrupt cell metabolism. Chlorine (a strong oxidant) antimicrobial action which inhibits bacterial enzymes leading to oxidation irreversible exhibits of the SH group (sulfidrile group) of the essential bacterial enzyme. ${ }^{24}$ In addition, $5 \% \mathrm{NaOCl}$ has a $\mathrm{pH}$ of 11 which is classified as very alkaline so that it can cause denaturation in bacterial cells. High $\mathrm{pH}$ sodium hypochlorite will disrupt the integrity of the cytoplasmic membrane by means of 
irreversible enzymatic inhibition, biosynthetic changes in cell metabolism and degradation of phospholipids. ${ }^{17}$ Sodium hypochlorite contains 2 substances with high oxidizing and disinfection effects, namely hypochlorous acid ( $\mathrm{HOCl})$ and hypochlorite ion (OCl-). The oxygen atom present in the HOCL substance is a very strong oxidant that is effective in killing bacteria and even viruses. ${ }^{17}$

In this study, $6 \%$ cocoa bark extract was used in order to find an effective antibacterial power that was not toxic. The choice of this concentration affects the content of chemical compounds, especially the flavonoid content of the cocoa shell extract. This statement is in line with research conducted by Rusliana in 1998 which stated that the concentration of cocoa husk extract affects the content of flavonoids, which are active phenolic compounds. ${ }^{25}$ In addition, a study conducted by Manik et al. In 2014 stated that the total flavonoid content affected the amount of antibacterial activity. As much as $93 \%$ of the antibacterial activity was influenced by the flavonoid content, which showed that the greater the flavonoid content the greater the antibacterial activity. ${ }^{26}$ Although the $6 \%$ cacao peel extract had lower antibacterial power than $5 \% \mathrm{NaOCl}$, based on the inhibition zone diameter category (table 2.1), the inhibition zone diameter produced by $6 \%$ ( 11.8375 $\mathrm{mm}$ ) cocoa peel extract was still categorized as strong antibacterial inhibitory power.

\section{CONCLUSION}

In this study, it can be concluded that there is a difference in antibacterial power between $6 \%$ cocoa peel extract compared to $5 \% \mathrm{NaOCl}$ against Lactobacillus acidophilus bacteria.

\section{REFERENCES}

1. Lalloo, R. Tadakamadla, S. K. Kroon, J. Tut, O. Kularatna, S. Boase, R. Kapellas, K. Gilchrist, Cobbledick, D.E. Rogers, J. and Johnson, N. W. 2019. Salivary characteristics and dental caries experience in remote Indigenous children in Australia: a cross-sectional study. BMC Oral Health. 19(21): 1-9

2. Ademe, D. Admassu, D. and Balakrishnan, S. 2020. Analysis of salivary level Lactobacillus spp. and associated factors as determinants of dental caries amongst primary school children in Harar town, eastern Ethiopia. BMC Pediatric. 20:18. 1-9

3. Mei,M.L. Zhao, I.S. Ito, L. Lo, E.C.M and Chu, C.H. 2015. Prevention of secondary caries by silver diamine fluoride. International Dental Journal. 66: 71-77.

4. Bin-Shuwaish, M. S. (2016). Effects and effectiveness of cavity disinfectants in operative dentistry: A literature review. Journal of Contemporary Dental Practice, 17(10), 867-879. Brzozowski B, Bednarski W, Dziuba B (2009). Functional properties of Lactobacillus acidophilus metabolites. J. Sci. Food Agric., 89(14): 2467-2476.

5. Mohammed, S.B. 2016. Effects and Effectiveness of Cavity Disinfectants in Operative Dentistry: A Literature Review. The Journal of Contemporary Dental Practice, October 2016;17(10):867-879
6. Kim, B.R., Oh, M.H., Shin, D.H. 2017. Effect of cavity disinfectants on antibacterial activity and microtensile bond

7. strength in class I cavity. Korea Selatan: Dental Materials Journal 2017; 36(3): 368-373.

8. Sassone, LM, Fidel RAS, Fidel SR, Dias M, Junior RH. Antimicrobial Activity of Different Concentration of $\mathrm{NaOCl}$ and Chlorhexidine Using a Contact Test. Bradz Dent J 2008; 14(2).

9. Sartini, at al. 2017. Pengaruh Pra Perlakuan Sebelum Pengeringan Sinar Matahari Dari Kulit Buah Kakao Terhadap Kadar Komponen Fenolik Dalam Ekstrak. Bioma : Jurnal Biologi Makassar, 2(1):15-20, 2017

10. Rachmawati., Mu'nisa, A. Hasri. 2017. Analisis Fitokimia Ekstrak Kulit Buah Kakao (Theobroma cacao L.) Sebagai Kandidat Antimikroba. Fakultas MIPA Universitas Negeri Makassar. 667-670.

11. Tunggul, F.S. Tonggi, I.L. 2020. Kadar Ndf Dan Adf Limbah Kulit Buah Kakao Yang Difermentasi Dengan Ragi Isi Rumen. Fakultas Peternakan Universitas HKBP Nommensen Medan

12. Fatmawati, E., Mahmud, Zainal., Syakir, M., Munarso, Joni., Ardana, I Ketut., 53 Rubiyo. (2010) Budidaya dan Pascapanen Kakao ${ }^{\text {ec }}$. Pusat Penelitian dan Pengembangan Perkebunan, pp. 1-12. doi: 10.3997/2214-4609.201404137.

13. Elkasses, D.W. Fawzi, E.M. Zohairy, A.E. 2014. The effect of cavity disinfectants on the micro-shear bond strength of dentin adhesives. Eur J Dent: 8(2): 184-190.

14. ASCIA, 2019. Chlorhexidine Allergy. https://www.allergy. org.au/patients/drug-allergy/chlorhexidine-allergy

15. Dubey, S. 2016. Comparative antimicrobial efficacy of herbalalternatives (Emblica officinalis, Psidium guajava), MTAD, and 2.5\% sodium hypochlorite against Enterococcus faecalis: An in vitro study. Elsevier: JOBCR-210; 1-4

16. Hermawan Sri, Yuli Rizky AN, Rosdanelli H, 2012, Penentuan Efisiensi Inhibisi Korosi Baja Menggunakan Ekstrak Kulit Buah Kakako (Theobroma cacao). Jurnal Teknik Kimia; 1 (2): 31-33.

17. Delost, M.D. 2014. Introduction to Diagnostic Microbiology for the Laboratory Sciences. Jones \& Bartlett: University Youngstown Ohio. pp. 120- 121.

18. Estrela, C. et al. 2002. Mechanism of action of sodium hypochlorite. Braz Dent J. 2002;13(2):113-7.

19. Nomer, N.M. at al. 2019. Kandungan Senyawa Flavonoid dan Antosianin Ekstrak Kayu Secang (Caesalpinia Sappan L.) serta Aktivitas Antibakteri terhadap Vibrio cholera. Jurnal Ilmu dan Teknologi Pangan Vol. 8, No. 2, 216-225.

20. Cavalieri, S.J., I.D. Rankin., R.J. Harbeck., R.S. Sautter., Y.S. McCarter., S.E. Sharp., J.H. Ortez., dan C.A. Spiegel. Manual of Antimicrobial Susceptibility Testing. USA: American Society for Microbiology. 2005.

21. Sari, F.P. dan S. M. Sari. Ekstraksi Zat Aktif Antimikroba dari Tanaman Yodium (Jatropha multifida Linn) sebagai Bahan Baku Alternatif Antibiotik Alami. Semarang: Fakultas Teknik Universitas Diponegoro. 2011.

22. Akiyama, H. K. Fujii. O. Yamasaki., T. Oono. K. Iwatsuki. AntibacterialAction of Several Tannin against Staphylococcus aureus. Journal of Antimicrobial Chemotherapy. 2001;48: $487-491$.

23. Cushnie, T.P.Tim. Lamb, Andrew J. Amtimicrobial Activity of Flavonoids. International Journal of Antimicrobial AgentsI. 2005;26: 343-356.

24. Ludwiczuk, A. et al. 2017. Terpenoids. Pages 233-266. https://doi.org/10.1016/B978-0-12-802104-0.00011-1

25. Nio, S., 2017. The effectiveness of heated sodiumhypochlorite on Enterococcus faecalis in infected dentinaltubules (Doctoral 
Conservative Dentistry Journal Vol. 11 No. 2 July-December 2021; 62-66

dissertation, University of British Columbia)

26. Rusliana, E. 1998. Ekstrak Kulit Buah Kakao (Theobroma Cacao). Fakultas Teknologi Pertanian Institut Pertanian Bogor
27. Manik, D.F. et al. 2014. Analisis Korelasi antara Kadar Flavonoid dengan Aktivitas Antibakteri Ekstrak Etanol dan Fraksi-Fraksi Daun Kersen (Muntingia calabura l.) terhadap Staphylococcus aureus. KHAZANAH, Vol. 6 No.2 